\title{
INISIATIF OPEN DATA PADA USAHA MIKRO KECIL MENENGAH
} KOTA BANDUNG

\author{
Thomas Bustomi ${ }^{1)}$, Achdiat ${ }^{2)}$, Endah Marlovia ${ }^{3)}$ \\ ${ }^{1,2,3}$ Universitas Pasundan Bandung, Kota Bandung, Jawa Barat, Indonesia \\ 1,2,3 thomas.bustomi@unpas.ac.id, achdiat@unpas.ac.id, endahmarlovia33@gmail.com \\ ABSTRAK
}

Kota Bandung memulai penerapan inisiatif open data pada 11 Desember 2015. Open data bagi Kota Bandung adalah sebuah prinsip keterbukaan sebagai bagian dari perbaikan proses manajerial pemerintahan agar pengambilan keputusan berjalan efektif dan efisien. Sejak diterapkan, Pemkot Bandung telah memanfaatkan open data secara konkret, salah satunya untuk memberikan informasi kepada masyarakat secara real-time (waktu nyata secara kuantitas) khususnya dalam bidang keuangan, perdagangan dan kesehatan. Penerapannya di sektor UMKM, ada banyak masalah yang dihadapi: keberlangsungan komitmen kepemimpinan, budaya birokrasi yang sebagian besar masih tertutup, kapabilitas yang rendah, kebijakan yang belum mendukung, standar dan kualitas data, kurangnya kegunaan, aksesibilitas data, dan juga kemampuan publik dari pengguna data untuk memahami dan memanfaatkan big data. Karenanya, penelitian ini secara teknis, ingin memahami tata kelola dalam penerapan open data di Kota Bandung dan proyeksi kedepan bagi UMKM dalam memanfaatkan open data untuk meningkatkan layanan dan produk melalui pemahaman big data. Penelitian ini menggunakan metode kualitatif dengan pendekatan studi kasus. Hasilnya, dalam kasus Kota Bandung tata kelola open data banyak dipengaruhi oleh komitmen kepemimpinan politik yang akan menentukan tindakan dari komitmen tersebut: kerangka kebijakan / hukum, struktur kelembagaan dan kapabilitas pemerintah, pasokan data dan permintaan data, keterlibatan dan kemampuan komunitas untuk membuka dan memanfaatkan data, dana untuk program open data, infrastruktur dan pemanfaatan teknologi, ceritacerita sukses dan pelibatan perguruan tinggi. Secara umum open data di Kota Bandung telah mencapai aspek transparansi, tetapi belum mencapai akuntabilitas dalam konsep pemerintahan terbuka. Disisi lain, sampai saat ini belum ada bukti yang cukup pemanfaatan open data bagi UMKM. Disarankan, dalam kasus sektor UMKM yang baru mengadopsi big data, memahami bahwa pelibatan seluruh pemangku kepentingan dalam ekosistem tata kelola open data: Pemerintah, komunitas, NGO, media, perguruan tinggi, swasta dan publik sangat penting untuk mencapai nilai-nilai yang dijanjikan open data.

Kata kunci: open data, tata kelola, big data, UMKM.

\begin{abstract}
The city of Bandung started the initiative to open data on December 11, 2015. Opening data for the city of Bandung is a principle as part of improving government managerial processes so that decision making is effective and efficient. Since its implementation, the Bandung City Government has made real use of open data, one of which is to provide information to the public in real-time (real time in quantity), especially in the fields of finance, trade and health. In its application in the MSME sector, there are many problems faced: leadership sustainability, culture that is still largely closed, low capabilities, unsupported policies, data standards and quality, lack of usability, data accessibility, and also the ability of public data users to understand and leveraging big data. Therefore, this research technically wants to understand governance in the application of open data in the city of Bandung and future forecasts for MSMEs in utilizing open data to improve services and products through understanding big data. This study uses a qualitative method with a case study approach. As a result, in the case of the City of Bandung, open data governance is heavily influenced by political commitments that will determine the actions of these commitments: the policy framework, institutional and government capabilities, data supply and data demand, community involvement and ability to open and utilize data, funding for programs open data, infrastructure and technology utilization, success stories and university involvement. In general, open data in Bandung City has achieved transparency, but has not yet achieved accountability in the concept of open government. On the other hand, until now there is not enough evidence for the use of open data for MSMEs. It is recommended, in the case of
\end{abstract}




\section{Kebijakan: Jurnal Ilmu Administrasi Volume 12, Nomor 2, Juni 2021 \\ E-ISSN: 2656-2820 \\ P-ISSN 1829-5762}

the MSME sector that has just adopted big data, understanding that the involvement of all stakeholders in the open data governance ecosystem: Government, communities, NGOs, media, universities, private, and public is very important to achieve open data values.

Keywords: open data, governance, big data, MSMEs.

\section{PENDAHULUAN}

Individu, kelompok, masyarakat, negara, dan interaksi sosial dalam skala global pada setiap satuan waktu menghasilkan gerak dan aktivitas yang membentuk ekosistem kehidupan. Fakta kehidupan tersebut menjadi kesatuan pengetahuan berupa data dan informasi dengan konteks masing-masing. Data mewakili secara deskriptif sebuah fakta. Jejaring data yang kompleks adalah gambaran kehidupan. Membuka, memahami dan memanfaatkan data akan sangat membantu bagaimana mengelola kehidupan sosial itu sendiri. Dalam sistem sosial, negara adalah institusi yang mempunyai legitimasi untuk membuka dan memanfaatkan data internal pemerintahan maupun warga negaranya.

Tingkat lokal, Kota Bandung memulai penerapan open data pada 11 Desember 2015 sebagai bagian dari komitmen keterbukaan pemerintah. Deklarasi dukungan 100\% wali kota Bandung terhadap gerakan keterbukaan data pada tanggal 5 Desember 2014 melatarbelakangi inisiatif ini. Bergabung dengan 4 daerah lainnya yaitu DKI Jakarta, Kabupaten Bojonegoro, Kota Semarang, dan Kota Banda Aceh, Kota Bandung menjadi salah satu pemerintah daerah yang mempelopori penerapan open data di Indonesia.

Ridwan Kamil, Wali kota Bandung pada acara International Open Data Day 2014 "Open Data for Development" (22/2/2014) di Institut Teknologi Bandung (ITB), meletakkan Pemerintahan Terbuka (Open Government) sebagai salah satu dari lima tonggak utama yang harus ditempuh oleh Kota Bandung menuju "Smart City", yaitu: infrastructure, smart government, open government, empowering, dan technopolis. Karakteristik Smart City yang memanfaatkan teknologi dalam pemerintahan diklaim akan menghasilkan berbagai solusi digital yang menggunakan open data, seperti aplikasi seluler, situs web, internet, hingga perangkat yang saling terintegrasi secara digital.

Kolaborasi menjadi nilai utama yang diusung oleh Kota Bandung agar penerapan open data dapat berjalan maksimal melalui kerjasama awal dengan Code for Bandung, West Java Incorporated Bank Indonesia Provinsi Jawa Barat, berbagai komunitas lokal dan nasional. Jumlah pengguna internet di Kota Bandung pada tahun 2016 menurut Tempo yang mencapai 579 ribu orang dan didominasi oleh generasi muda, menjadi peluang bagi pemerintah meningkatkan partisipasi dan kolaborasi masyarakat. Pemerintah Kota (Pemkot) Bandung memperkirakan $85-95 \%$ masyarakat telah memiliki literasi teknologi yang memadai.

Pemkot Bandung telah melakukan berbagai kegiatan dan kerja sama untuk menyukseskan open data Kota Bandung, antara lain menyelenggarakan Data Discovery Workshop (DDW), sebuah acara untuk mensosialisasikan dan menerima umpan balik dari pengguna data, dan mengajarkan Aparatur Sipil Negara (ASN) di lingkungan Dinas, Kecamatan, dan Kelurahan. Open Data Summit and Challenge (BOSCHA), juga diselenggarakan untuk memperkaya ekosistem open data. BOSCHA diinisiasi oleh komunitas Code for Bandung, yang merupakan konferensi dan kompetisi pengembangan aplikasi terkait open data. BOSCHA ditujukan untuk mempertemukan dan meningkatkan kolaborasi antar pemangku kepentingan dalam ekosistem open data.

Berdasarkan Road Map Open Data Bandung 2019 dan observasi awal telah diidentifikasi keadaan awal komponen-komponen pendukung open data Bandung yang dilihat dari Tata Kelola, Teknologi, Sumber Daya Manusia, dan organisasi.

Komponen tata kelola terdapat beberapa keadaan yang telah diamati, keadaan-keadaan tersebut antara lain: Dataset yang siap diunggah (telah terunggah) pada portal open ada masih terbatas, yaitu sekitar 1040 dataset; Belum terdapat tata kelola open data Kota Bandung Terdapat enam alur kerja proses open data di Bandung, yaitu: data discovery, pengumpulan data, verifikasi data, penyesuaian format data, validasi data, 


\section{Kebijakan: Jurnal Ilmu Administrasi Volume 12, Nomor 2, Juni 2021 \\ E-ISSN: 2656-2820 \\ P-ISSN 1829-5762}

dan publikasi data; Telah dilaksanakan beberapa kegiatan dalam pengelolaan sumber daya manusia berupa pelatihan untuk beberapa SKPD

Keadaan komponen teknologi yang telah diamati saat ini antara lain: Kualitas data secara keseluruhan masih berada pada level bintang satu; Tidak semua dinas menyediakan website (aktif); Terdapat website PPID yang digunakan untuk permohonan pembukaan data secara online; Belum terdapat integrasi data antar dinas; Beberapa bidang pada dinas masih belum melakukan komputerisasi data; Pengembangan portal data sudah menggunakan CKAN

Keadaan saat ini dari sisi sumber daya manusia meliputi: Hanya pedasi pada sebagian dinas saja yang telah menunjukkan kinerja yang baik dalam pengelolaan open data di SKPD masing-masing. Kurangnya pelatihan bagi pedasi. Keadaan saat ini dari sisi organisasi: Belum ada pembagian peran dan tanggung jawab yang jelas antara Dinas Penanaman Modal dan Pelayanan Terpadu Satu Pintu dan Bappelitbang terkait pengelolaan program open data Kota Bandung; Belum ada anggaran khusus terkait program open data; Belum ada payung hukum dan petunjuk teknis pengelolaan open data.

Pada Usaha Mikro Kecil Menengah (UMKM), open data terkait soal ketersediaan informasi , pelatihan, ijin , peluang pasar, pemodalan, namun sebenarnya open data bukan kearah hal tersebut yang hanya menyajikan olahan informasi menjadi sebuah data saja, tetapi bagaimana open data digunakan untuk mengolah data menjadi suatu keputusan dalam pengambilan kebijakan, Sisi open data sebenarnya lebih kepada data terkait kecenderungan konsumsi, jenis-henis umkm, sumber daya manusia, arus modal, yang paling krusial sebenarnya data konsumen apabila dinas minimal berpikir kearah tersebut. Adanya open data apabila dimanfaatkan dengan benar maka dapat meningkatkan pendapatan UMKM. Fenomena gofood misalnya mengapa berhasil sederhananya mereka betul-betul memanfaatkan data konsumen yang dianalisa sedemikian rupa (big data) untuk menghasilkan produk dan layanan melalui teknologi. Masalahnya gofood itu swasta, pemerintah bisa tidak? Sebenarnya data di pemerintah banyak sekali, tetapi standar dan tingkat interobilitasnya sangat buruk.

Banyak yang belum menyadari pentingnya open data dengan memanfaatkan big data dan memahami fakta bahwa hal itu dapat dimanfaatkan dengan berbagai cara jika digunakan dengan benar. Survei telah membuktikan bahwa potensi Big Data belum dipahami dan digunakan secara maksimal untuk membantu pelaku bisnis membuat keputusan bisnis yang lebih cerdas dan mendorong operasi bisnis yang efisien. Seiring peran data yang berkembang, semakin banyak bisnis yang mulai mengadopsi teknologi transformatif untuk mengatur dan menganalisa data berharga mereka.

Kondisi open data Kota Bandung saat ini adalah merapihkan standar data, pelatihan sumber daya manusia, dan yang terkait dengan manajemen data di setiap internal dinas masing-masing. Dampak kecilnya terkait harga-harga bahan pokok yang sebenarnya hal itu baru sekedar informasi yang diolah untuk menghasilkan data, belum sampai pada pengambilan kebijakan dan data mentah untuk diolah dalam pengambilan keputusan. Usaha Mikro Kecil Menengah belum terlihat kearah sana, padahal salah satu tujuannya untuk meningkatkan ekonomi dan investasi. Apakah potensi open data untuk UMKM tidak ada? jawabannya sangat potensial, tetapi memang kondisinya belum signifikan. Data sendiri merupakan titik kunci dari revolusi 4.0, siapa yang mengelola data dengan benar maka dia yang menang baik pada sektor publik maupun swasta.

Setiap sektor memiliki lingkungan yang kompetitif di mana UMKM harus berjuang keras untuk bertahan. Big Data dapat menawarkan kesempatan untuk mengumpulkan semua data tentang bisnis mereka, supplier, partner, dan bahkan pelanggan mereka sendiri yang dengannya mereka dapat melakukan analisis mendalam untuk menemukan peluang yang ada di setiap sektor, sehingga menghasilkan insight untuk bersaing dengan perusahaan-perusahaan besar. Hambatan terbesar UMKM dalam menggunakan Big Data adalah biaya,. yang pada akhirnya, harus menyadari bahwa Big Data telah dianggap sebagai konsep penting untuk mendapat keunggulan kompetitif dalam bisnis.

\section{METODE}

Penelitian ini menggunakan metode kualitatif dengan pendekatan studi kasus. Peneliti mengeksplorasi kehidupan nyata, sistem terbatas kontemporer (kasus) melalui pengumpulan data yang 


\section{Kebijakan: Jurnal Ilmu Administrasi Volume 12, Nomor 2, Juni 2021 \\ E-ISSN: 2656-2820 \\ P-ISSN 1829-5762}

detail dan mendalam yang melibatkan beragam sumber informasi (misalnya wawancara, pengamatan, bahan audiovisual, dokumen dan berbagai laporan, dan melaporkan deskripsi kasus dan tema kasus (Creswell, 2014: 135).

Dilihat dari kasus yang diteliti, menurut Endraswara dalam Rahardjo (2017: 6) studi kasus dapat dibagi menjadi dua golongan, yaitu studi kasus berupa penyimpangan dari kewajaran dan studi kasus ke arah perkembangan yang positif. Studi kasus pertama bersifat kuratif, dan disebut studi kasus retrospektif (retrospective case study), yang memungkinkan ada tindak lanjut penyembuhan atau perbaikan dari suatu kasus (treatment). Tindak "penyembuhan" tidak harus dilakukan oleh peneliti, tetapi oleh orang lain yang kompeten. Peneliti hanya memberikan masukan dari hasil penelitian. Sedangkan yang kedua disebut studi kasus prospektif (prospective case study). Jenis Studi Kasus ini diperlukan untuk menemukan kecenderungan dan arah perkembangan suatu kasus. Tindak lanjutnya berupa Penelitian Tindaan (Action Research) yang dilakukan juga oleh pihak lain yang berkompeten. Tipe studi kasus yang dipakai dalam penelitian ini adalah studi kasus intrinsik yang fokusnya adalah pada kasus itu sendiri, yang dalam hal ini adalah tata kelola open data untuk meningkatkan income UMKM di Kotak Bandung.

\section{Landasan Teori}

Berikut ini indikator faktor keberhasilan open data (Stagars, 2016):

1. Perundang-undangan, peraturan dan perizinan
a) Kerangka hukum yang kuat untuk menerbitkan data pemerintah, menangani risiko dan kekhawatiran badan pemerintah.
b) Peraturan operasional dalam mempublikasikan data.
c) Kebijakan untuk kolaborasi antara lembaga dalam prakarsa data terbuka.
d) Kebijakan yang memastikan kemudahan penggunaan data bagi pengguna data.
e) Informasi tentang undang-undang privasi dan bagaimana data terbuka dapat sesuai dengan Informasi tentang makna dan implikasi dari lisensi.

2. Gugus tugas atau agen yang ditunjuk

a) Pembuatan agen atau gugus tugas yang ditunjuk yang bertanggung jawab atas infrastruktur, inisiatif, dan proses data yang terbuka. Di negara dengan penggunaan data yang berhasil dibuka, keterlibatan pemain kunci lainnya seperti komunitas memberikan kisah sukses.

3. Insentif untuk mendorong penggunaan data

a) Skema insentif untuk melibatkan warga dalam penggunaan data terbuka.

b) Dorongan inkubator startup berbasis data terbuka.

c) Dorongan model bisnis untuk memungkinkan perusahaan mengembangkan layanan tambahan di atas platform data terbuka.

d) Membangun komunitas berorientasi masalah melalui acara partisipatif seperti acara, kompetisi, dan hackathons (acara kolaborasi pengembangan proyek perangkat lunak) dengan kurikulum universitas, penghargaan, festival, dan sebagainya.

4. Pelatihan dan dukungan untuk penyedia data dan pengguna, Interaksi, Umpan balik, dan Keberlanjutan.

a) Layanan dukungan profesional dan pelatihan untuk pengguna data terbuka yang potensial.

b) Acara untuk mengkomunikasikan manfaat potensial dari data terbuka kepada pengguna.

c) Sebuah lingkungan belajar bagi instansi pemerintah.

d) Interaksi antara penyedia data dan pengguna data untuk merangsang rantai pasokan dan permintaan dataset.

e) Mekanisme instansi pemerintah untuk diketahui bagaimana orang menggunakan datanya.

f) Mekanisme instansi pemerintah untuk mengetahui apa yang dapat mereka pelajari dari penggunaan kembali datanya.

g) Mekanisme lembaga pemerintah untuk mengetahui bagaimana mereka dapat memperbaiki publikasi data mereka dari umpan balik pengguna

5. Penelitian dan pendidikan

a) Universitas dan kurikulum pendidikan berkelanjutan tentang data terbuka. 


\section{Kebijakan: Jurnal Ilmu Administrasi}

Volume 12, Nomor 2, Juni 2021

E-ISSN: 2656-2820

P-ISSN 1829-5762

b) Roadmap untuk area penelitian tentang data terbuka untuk mengkonsolidasikan upaya penelitian dan mengatasi masalah terbuka

\section{Kerangka Berpikir}

Administrasi Publik mengalami pergeseran dalam konsep tata kelola dan pemerintahan, dengan nilai utama yaitu: akuntabilitas, transparansi, kepercayaan publik. Selain itu, pergeseran manajemen pemerintahan terjadi dengan menguatnya pembuatan kebijakan berbasis bukti.

Konsep umum tentang tata kelola pemerintahan (governance) di era digital, open data dipengaruhi oleh banyak faktor dari dua indikator yang dipakai yaitu Stagars (2016)). Hal lainnya, revolusi 4.0 salah satunya mensyaratkan adanya open data. Transparansi dan akuntabilitas adalah argumen dasar akan keniscayaan lembaga pemerintah untuk mempublikasikan open data, penting untuk memanfaatkan nilai potensial data bagi penggunaan secara internal oleh para pembuat kebijakan. Mempublikasikan data melalui konsep open data dalam bentuk yang baku (mentah), merupakan cara yang sangat penting untuk memperoleh informasi dan menyajikan bukti penting yang dibutuhkan untuk pembuatan kebijakan oleh pemerintah.

open data adalah sebuah konsep yang dapat menjadi jalan menuju terwujudnya pemerintahan terbuka. Dengan memiliki transparasi dan akuntabilitas kebijakan. Hasil dari open data adalah sebagai dasar dari pembuatan kebijakan berbasis bukti.

Kondisi open data Kota Bandung saat ini adalah merapihkan standar data, pelatihan sumber daya manusia, dan yang terkait dengan manajemen data di setiap internal dinas masing-masing. Dampak kecilnya terkait harga-harga bahan pokok yang sebenarnya hal itu baru sekedar data yang diolah untuk menghasilkan informasi, belum sampai pada pengambilan kebijakan dan data mentah untuk diolah dalam pengambilan keputusan. Usaha Mikro Kecil Menengah (UMKM) belum terlihat kearah sana, padahal salah satu tujuannya untuk meningkatkan ekonomi dan investasi. Apakah potensi open data untuk UMKM tidak ada? jawabannya sangat potensial, tetapi memang kondisinya belum signifikan. Data sendiri merupakan titik kunci dari revolusi 4.0, siapa yang mengelola data dengan benar maka dia yang menang baik pada sektor publik maupun swasta.



Gambar1. Kerangka Bepikir 


\section{Kebijakan: Jurnal Ilmu Administrasi Volume 12, Nomor 2, Juni 2021 \\ E-ISSN: 2656-2820 \\ P-ISSN 1829-5762}

\section{Lokasi dan Waktu Penelitian}

Penelitian ini dilakukan pada Dinas Komunikasi dan Informatika (Diskominfo) Kota Bandung c.q Unit Open Data Bidang Data dan Statistik, dan Dinas Koperasi Usaha Mikro Kecil Menengah.

Lamanya Penelitian yaitu pelaksanaan penelitian dari Desember 2019- Juli 2020.

\section{PEMBAHASAN}

Raison d'etre atau alasan keberadaan open data di Kota Bandung dapat ditelusuri ketika Wali kota saat itu yang baru dilantik, Ridwan Kamil pada Februari 2014 menyampaikan konsep pembangunan Kota Bandung di masa depan pada acara International Open Data Day 2014. Ia mengidentifikasi tiga masalah utama Kota Bandung. Pertama, masalah infrastruktur (yang menyebabkan banjir, sampah, dan kemacetan). Kedua, manajemen internal pemerintahan: birokrasi, pengelolaan yang membuat pengambilan keputusan lambat, dan ketiga pola pikir warga.

"Dulu, saya kultur kerja cepat. Kini jadi Wali kota ambil keputusan lama, kebutuhan data untuk pengambilan keputusan. Banyak data yang tidak terinformasikan membuat hidup susah. Misalnya dana bansos, karena tidak transparan, diakses oleh penwe $\quad$ lkiq78uerima gelap. Pada saat data itu tidak dapat diakses, pada saat data itu manual itu berakumulasi pada ketidakefisienan proses pengambilan keputusan" (Kutipan pidato Ridwan Kamil pada International Open Data Day 2014 "Open Data for Development” [22/2/2014] di ITB)

Dikesempatan lain dalam acara Bandung Open Data Summit and Challenge (BOSCHA) pada Februari 2015, Ridwan Kamil menyampaikan:

"Keterbukaan harus menjadi prinsip bahwa apa yang kita kerjakan ini selama itu urusannya untuk kepentingan masyarakat disitulah keterbukaan harus dihadirkan. Bahasa kerennya, open data. Data ini hadir dalam hidup kita menjadi sebuah kebutuhan agar hidup bisa lebih efisien" (Kutipan pidato Ridwan Kamil pada Bandung Open Data Summit and Challenge (BOSCHA) [21/2/2015] di Bank Indonesia Perwakilan Jawa Barat)

Dari dua kutipan pernyataan tersebut, dapat diinterpretasi bahwa open data bagi Kota Bandung adalah sebuah prinsip keterbukaan sebagai bagian dari perbaikan proses manajerial pemerintahan agar pengambilan keputusan berjalan efisien. Secara garis besar, komitmen Pemkot Bandung telah menunjukkan upaya yang cukup dan patut diapresiasi untuk menerapkan open data.

Selama berjalan 5 tahun, open data Kota Bandung berfokus pada dua hal. Pertama, pembangunan kapasitas (capacity building) internal pemerintah untuk menyamakan persepsi dan peningkatan kompetensi. Kedua, melakukan sosialisasi melalui serangkaian kegiatan kolaborasi untuk meningkatkan partisipasi dengan komunitas dan publik yang memiliki kemampuan untuk memanfaatkan open data. Hal tersebut sebagaimana tertuang dalam "Peta Jalan Open Data Kota Bandung 2016-2020", yang memuat rencana aksi dan program setiap tahunnya.

Pemanfaatan open data yang telah dirilis untuk publik adalah salah satu isu utama tata kelola open data di Kota Bandung. Ketika data telah dibuka dan dapat diakses, aspek transparansi misalnya terkait penggunaan Anggaran Pendapatan dan Belanja Daerah (APBD) telah dilalui. Namun, apakah data terbuka dapat menjadi sesuatu yang bernilai, seperti inovasi untuk memecahkan berbagai masalah perkotaan dan basis pengambilan kebijakan berbasis bukti menjadi pertanyaan penting untuk selanjutnya untuk dijawab.

Tata kelola open data di Kota Bandung yang diidentifikasi meliputi komitmen pemerintah, kerangka kebijakan / hukum, struktur kelembagaan dan kapabilitas pemerintah, pasokan data dan permintaan data, keterlibatan dan kemampuan komunitas untuk membuka dan memanfaatkan data, dana untuk program open data, infrastruktur dan pemanfaatan teknologi, cerita-cerita sukses (sosialisasi) dan peran perguruan tinggi. 


\section{Kebijakan: Jurnal Ilmu Administrasi Volume 12, Nomor 2, Juni 2021 \\ E-ISSN: 2656-2820 \\ P-ISSN 1829-5762}

Open data memang menjanjikan dampak yang luar biasa bila berhasil diterapkan dengan baik. Hasil telaah dari berbagai riset dan contoh sukses di berbagai negara (dalam skala nasonal maupun wilayah) telah membuktikan hal tersebut. Bahkan, di era ketika dunia fisik, digital dan biologi terus menyatu yang disebut sebagai revolusi industri 4.0 saat ini, open data menurut World Economic Forum (WEF) akan menentukan negara mana yang berada di garis depan revolusi industri 4.0.

Namun demikian, sesuai dengan dampak positif yang dihasilkan, open data mensyaratkan tata kelola yang holistik dan cenderung rumit. Open data adalah sesuatu yang kompleks, umumnya bagi Indonesia dan khususnya Kota Bandung yang baru mengadopsi konsep pemerintahan terbuka karena membutuhkan pemahaman, kompetensi dan komitmen, untuk mendukung dan terlibat secara terus menerus dari semua pihak: pemerintah, komunitas, perguruan tinggi, media, sektor swasta dan masyarakat sebagai syarat untuk melakukan kolaborasi dan partisipasi aktif.

Adanya peraturan mengenai pentingnya data dimulai dari kemunculanya OGI, memperlihatkan bahwa Big Data dapat menawarkan usaha kecil dan menengah kesempatan untuk mengumpulkan semua data tentang bisnis-bisnis mereka, supplier, partner, dan juga pelanggan mereka, hasil dari data-data ini dapat menghasilkan insight yang membuat perusahaan-perusahaan ini bersaing dengan perusahaan besar.

Big Data adalah bentuk data terstruktur maupun tidak terstruktur dalam ukuran besar dan kompleks yang diciptakan dari berbagai sumber. Pengaruh Big Data terdapat tidak hanya pada jumlah data yang dihasilkan namun juga dalam bagaimana data dapat diubah menjadi insight untuk bisnis. big Data telah 'mengganggu' berbagai industri sejak penemuannya. Termasuk bisnis kecil dan menengah. Pembuat keputusan harus menentukan sedari awal data mana atau berapa banyak data yang mereka harus gunakan untuk meningkatkan efisiensi bisnis mereka, sehingga mereka dapat membuat keputusan yang tepat. Analisis ini hanya mungkin bila perusahaan memiliki visi yang jelas mengenai kebutuhan, target, dan hasil yang diinginkan.

Setiap sektor memiliki lingkungan yang kompetitif di mana UMKM harus berjuang keras untuk bertahan. Big Data dapat menawarkan kesempatan kepada UMKM ini untuk mengumpulkan semua data tentang bisnis mereka, supplier, partner, dan bahkan pelanggan mereka sendiri yang dengannya mereka dapat melakukan analisis mendalam untuk menemukan peluang yang ada di setiap sektor, sehingga menghasilkan insight untuk bersaing dengan perusahaan-perusahaan besar. Hambatan terbesar UMKM dalam menggunakan Big Data adalah biaya,. yang pada akhirnya, UMKM harus menyadari bahwa Big Data telah dianggap sebagai konsep penting untuk mendapat keunggulan kompetitif dalam bisnis.

Secara umum, Big Data digunakan hampir di setiap industri di Indonesia, terutama di era Revolusi Industri 4.0 ini. Secara khusus, mayoritas perusahaan-perusahaan rintisan (startup) dari berbagai sektor menggunakan teknologi tersebut dalam menjalankan bisnis mereka. Contohnya, Kredivo yang menjadikan analisis Big Data sebagai dasar dari penilaian kredit di aplikasi mereka. Begitu pula dengan Loket yang berada di bawah naungan Go-Jek. Platform penjualan tiket dan pembuatan event itu memanfaatkan Big Data untuk menghasilkam produk-produk baru yang sesuai dengan karakteristik pasar mereka.

Solusi big data tak hanya diperuntukan untuk perusahaan besar di sektor telekomunikasi, jasa keuangan, minyak \& gas, dan ritel, tapi juga kalangan pengusaha kecil dan menengah. Yang menjadi masalah bukan besarnya dana investasi yang dibutuhkan, tetapi ada-tidaknya keinginan untuk menerapkan teknologi tersebut demi meningkatkan pendapatan perusahaan.

UMKM sesungguhnya sudah bisa memanfaatkan teknologi big data karena tak sedikit yang sudah memiliki website. Dari web, mereka tentu memiliki data interaksi. Nah, data interaksi itulah yang kemudian dianalisis. Contoh klasik big data itu adalah 'klik' yang terjadi di website. Mereka harus tahu apa yang sering konsumen 'klik'. Itu yang seharusnya diperhatikan karena akan men-drive konsumen untuk membeli sebuah produk. Misalnya, jual-beli, UMKM zaman sekarang pasti sudah banyak yang menjual secara online. Jadi, big data bisa diaplikasikan.

Dari segi Perundangan atau peraturan mengenai pelaksanaan open data ini yaitu UU No. 14/2008 mengenai Keterbukaan Informasi Publik. Undang-undang yang juga dikenal sebagai UU KIP ini 


\section{Kebijakan: Jurnal Ilmu Administrasi Volume 12, Nomor 2, Juni 2021 \\ E-ISSN: 2656-2820 \\ P-ISSN 1829-5762}

kemudian dilanjutkan dalam peraturan pemerintah melalui PP No. 61/2010. Bahkan kini sudah ada Peraturan Presiden Nomor 39 Tahun 2019 tentang Satu Data Indonesia.

Gugus tugas atau unit yang ditunjuk untuk peningkatan UMKM adalah Dinas Koperasi dan Usaha Mikro Kecil Menengah Kota Bandung. Arah kebijakan dinas yaitu meningkatkan kualitas kelembagaan, produktivitas, daya saing dan kemandirian. Dinas KUMKM belum mengolah data yang ada dengan analisa big data dan belum menerapkan big data dalam pemecahan masalah dalam kegiatan usaha.

Insentuf untuk mendorong penggunaan data, anggaran yang berkaitan dengan open data pada dinas KUMKM Kota Bandung hanya berasal dari APBD Kota Bandung, sempat mengajukan ke provinsi namun tidak di ACC. Selain anggaran terhadap pengembangan data, juga terdapat anggaran pemodalan. Menggelar kegiatan gathering fasilitas intermediasi akses pembiayaan UMKM. Kegiatan ini dibuat sebagai sebuah media, dimana para pelaku usaha yang ada di kota Bandung bisa mengungkapkan berbagai keluhan dan permasalahan dalam mengakses permodalan.

Pelatihan dan dukungan, dinas KUMKM Kota Bandung,memberikan pelatihan tentang kewirausahaan dari brand ritel ternama, mereka dilatih bidang manajemen, mutu produk dan kemasan. Dinas KUMKM juga telah memberikan pendampingan bagi pelaku UMKM. Kebutuhan pendamping usaha mikro kecil menengah (UMKM) di Kota Bandung sangat tinggi. Saat ini rasio jumlah pendamping dengan pelaku usaha di Kota Bandung masih belum ideal. Pendamping diperlukan untuk mengakselerasi UMKM naik kelas.

Penelitian dan Pendidikan, baru sampai pada tahap penmanfaatan teknologi untuk pemasaran produk dan bagaiamana pengemasan produk . Kedua hal ini bekerja sama dengan PT Telekomunikasi Indonesia Tbk (Telkom) dan Institut Teknologi Bandung (ITB) membuka pelatihan pengembangan usaha di diharapkan mampu meningkatkan kompetensi, daya saing dan pemberdayaan UMKM .

Pembuatan model dengan pemanfaatan Big data dalam UMKM peneliti menggunakan metode system thingking dengan model causal loop diagram. Dalam kehidupan sehari-hari, baik kehidupan di dalam masyarakat maupun kehidupan dalam sebuah organisasi pasti sangat banyak kejadian yang terjadi, baik kejadian yang bersifat positif maupun kejadian yang bersifat negatif. Setiap kejadian - kejadian yang ada tentunya harus dipahami dengan benar secara keseluruhan dan mendalam, agar kejadian yang bersifat positif dapat dilanjutkan dan kejadian yang bersifat negatif dapat dicegah agar tidak terulang kembali. Cara untuk memahami setiap kejadian yang ada diperlukan sebuah proses untuk memahami suatu permasalahan dari penyebab hingga akibat, dari awal hingga akhir, dan juga keterkaitan antaran satu hal dengan hal lainnya sebagai sebuah hubungan sebab dan akibat, yang sering disebut dengan System

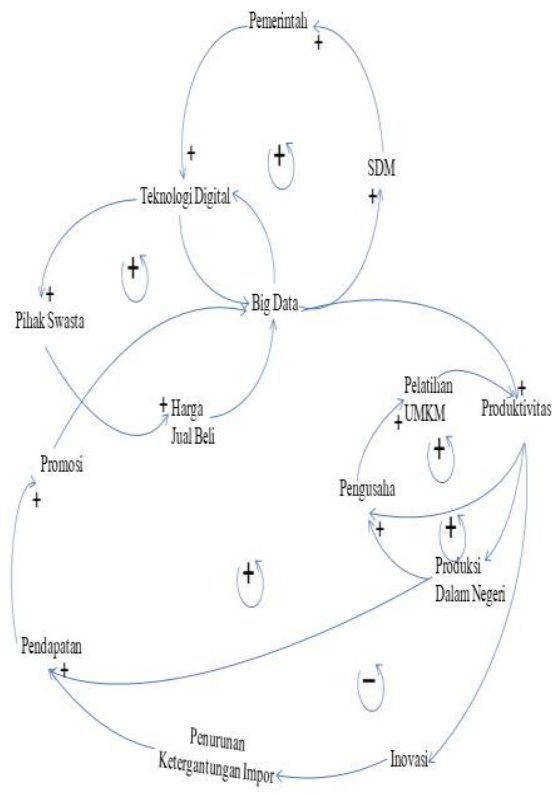




\section{Kebijakan: Jurnal Ilmu Administrasi Volume 12, Nomor 2, Juni 2021 \\ E-ISSN: 2656-2820 \\ P-ISSN 1829-5762}

Thinking.

Metode System Thinking memiliki berbagai tools dalam melihat sebuah situasi menyeluruh yang saling berhubungan, diantaranya adalah Model Causal Loop Diagram (CLD). Model Causal Loop Diagram (CLD) atau yang sering juga dikenal dengan diagram sebab akibat adalah model yang digunakan dalam sebuah pemecahan maupun pencegahan masalah dengan melihat setiap faktor yang ada berkaitan dengan faktor-faktor lainnya.

\section{Gambar 6.1. Model Pemanfaatan Big Data UMKM}

Dari gambar diatas bahwa terdapat 13 elemen yang dapat meningkatkan sektor UMKM dengan pemanfaatan big data yang benar. Dari gambar tersebut menujukkan beberapa hal dari loop yang dihasilkan yakni

1. Big data berdampak positif pada SDM dan berdampak positif pada pemerintah sehingga meningkatkan pelayanan dengan teknologi digital.

2. Big data dapat meningkatkan produktivitas dan berdampak pada produksi negeri sehingga dapat menurunkan konsumsi barang impor dan menaikan pendapatan pelaku UMKM, karena konsumsi dalam negeri meningkat maka UMKM membutuhkan promosi yang baik dengan pemanfaatan big data.

3. Produksi dalam negeri yang meningkat dapat membuat pengusaha lebih kreatif dalam mengembangkan usahanya dengan membuat bermacam-macam inovasi sehingga memerlukan pelatihan

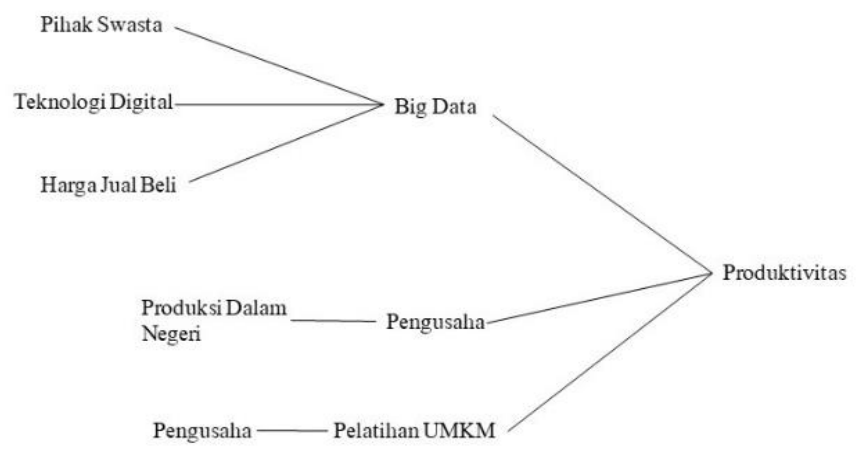

bagi pelaku UMKM , dengan adanya pelatihan juga mampu meningkatkan produktivitas, dan pelaku UMKM yang memiliki kreativitas dan inovasi akan meningkatkan produktivitas.

4. Big data dapat meningkatkan teknologi digital sehingga membutuhkan sinergitas dengan pihak swasta untuk menciptakan layanan dan produk dengan kualitas yang baik, dan harga jual belipun meningkat. Kegiatan jual beli yang tinggi akan meningkatkan pemanfaatan big data.

\section{Gambar 6.3. Umpan Balik Model Pemanfaatan Big Data}

Kesimpulannya terdapat 6 loop, dengan 5 loop positif dan 1 loop negatif, maka nilai loop nya positif yang menggambarkan umpan balik dalam setiap elementnya.

\section{SIMPULAN}

Indikator yang telah diidentifikasi dari tata kelola open data meliputi komitmen pemerintah, kerangka kebijakan / hukum, struktur kelembagaan dan kapabilitas pemerintah, pasokan data dan permintaan data, keterlibatan dan kemampuan komunitas untuk membuka dan memanfaatkan data, dana untuk program open data, infrastruktur dan pemanfaatan teknologi, cerita-cerita sukses dan peran perguruan tinggi.

Komitmen pemerintah dalam artian kepemimpinan politik secara umum cukup sebagai dasar inisiatif keterbukaan, tetapi perlu upaya yang lebih untuk menyamakan tingkat komitmen tersebut disemua level pemerintahan: SKPD dan ASN. Kebijakan dan kerangka hukum yang ada saat ini belum memadai untuk mendukung tata kelola open data sehingga penting dan mendesak untuk membuat 


\section{Kebijakan: Jurnal Ilmu Administrasi Volume 12, Nomor 2, Juni 2021 \\ E-ISSN: 2656-2820 \\ P-ISSN 1829-5762}

kebijakan teknis ditingkat daerah sebagai landasan yang memberi arah dan kejelasan penerapan open data. Struktur kelembagaan menghadapi tantangan koordinasi dan komunikasi lintas SKPD, pada sisi lain kapabilitas secara keseluruhan belum banyak ASN yang memiliki kemampuan yang diperlukan untuk mendukung open data.

Belum adanya kebijakan teknis berpengaruh terhadap pasokan data yang berjalan lambat dengan realisasi setengah dari proyeksi dataset yang ingin dibuka ke publik. Mayoritas data yang diminta publik terkait kependudukan, walaupun secara umum permintaan data dari publik belum terlalu signifikan.

Secara kuantitas komunitas di Kota Bandung potensial untuk memanfaatkan open data, akan tetapi keterlibatan komunitas untuk memanfaatkannya masih minim. Faktor tersebut disebabkan pasokan dataset yang dibuka pemerintah belum memperhatikan tingkat kegunaannya, walaupun disisi lain aspek transparansi tercapai.

Dana untuk penerapan open data berasal dari APBD. Ketersediaan infrastruktur pendukung penerapan open data telah tersedia, tetapi yang menjadi catatan adalah kapabilitas ASN untuk menggunakannya. Dari sisi masyarakat, belum ada riset yang menjadi bukti preferensi dan tingkat pemanfaatan teknologi. Kecenderungannya, pemanfaatan aplikasi oleh masyarakat belum menjadi sebuah kebiasaan. Sejauh ini, contoh sukses penerapan open data terwujud dalam ARIMBI, sebuah aplikasi real time yang berisi data pada bidang perdagangan, kesehatan, lalu lintas dan iklim (udara). Sedangkan pemanfaatan open data sebagai dasar bagi kebijakan berbasis bukti belum ditemukan bukti yang kuat, walaupun ada proyeksi yang mengarah pada solusi untuk mengatasi masalah kemacetan dan banjir. Pelaku UMKM di Kota Bandung banyak yang belum menyadari pentingnya Big Data dan memahami fakta bahwa hal itu dapat dimanfaatkan dengan berbagai cara jika digunakan dengan benar.

Potensi Big Data belum dipahami dan digunakan secara maksimal untuk membantu pelaku bisnis membuat keputusan bisnis yang lebih cerdas dan mendorong operasi bisnis yang efisien. Seiring peran data yang berkembang, semakin banyak bisnis yang mulai mengadopsi teknologi transformatif untuk mengatur dan menganalisa data berharga mereka.

\section{DAFTAR PUSTAKA}

\section{A. Buku}

Creswell, John W. 2014. Penelitian Kualitatif dan Desain Riset: Memilih diantara Lima Pendekatan Edisi ke-3. Yogyakarta: Pustaka Pelajar

Hay, Colin. 2015. "Globalisasi dan Kebijakan Publik". Dalam Goodin, Robert E. 2015. Handbook Kebijakan Publik, Bandung: Nusa Media

Hood, Christopher. 2015. "Alat-Alat Pemerintah di Era Informasi”. Dalam Goodin, Robert E. 2015. Handbook Kebijakan Publik, Bandung: Nusa Media

\section{B. Buku Elektronik}

Bauer, Florian dan Kaltenböck, Martin. 2012. Linked Open Data: The Essentials A Quick Start Guide for Decision Makers. Vienna: Monochrom

Bevir, Mark. 2013. A The Theory of Governance. California: The Regents of the University of California

Dickinson, Helen. 2016. From New Public Management to New Public Governance: The Implications for A 'New Public Service'. Camberra: The Australian National University Press

Fioretti, Marco. 2010. Why Open Digital Standards Matter dalam Government in Lathrop, D, Ruma, L, \& Fung, A., 2010, Open Government: Collaboration, transparency, and participation in practice. Cambridge: O'Reilly.

Frederickson, H. George. 2012. The Primer Theory of Public Administration. Colorado: Westview Press 


\section{Kebijakan: Jurnal Ilmu Administrasi}

Volume 12, Nomor 2, Juni 2021

E-ISSN: 2656-2820

P-ISSN 1829-5762

GildenHuys, J. S. H. 2004. The Philosophy of Public Administration: A Holistic Approach. Stellenbosch: Sun Press

Janet V. Denhardt and Robert B. Denhardt. 2007. The New Public Service: Serving, Not Steering. New York: M.E. Sharpe, Inc

O’Reilly, T. 2010. Government As a Platform, in Lathrop, D, Ruma, L, \& Fung, A 2010, Open Government: Collaboration, Transparency, and Participation in Practice. Cambridge: O'Reilly.

Rhodes, R.A.W. 2017. Governance and Public Administration. Newcastle Upon Tyne: University of Newcastle

Sivarajah, et. al. 2016. The Role of e-Participation and Open Data in Evidence-Based Policy Decision Making in Local Government. Uxbridge: Brunel University London

Stagars, M. 2016. Open Data In Southeast Asia. United Kingdom: Palgrave Macmillan

Yin, Robert K. 2011. Qualitative Research from Start to Finish. New York: The Guilford Press

Young, Andrew \& Verhulst, Stefaan, 2016. The Global Impact of Open Data Key: Findings from Detailed Case Studies Around the World. Sebastopol: O'Reilly Media, Inc.

C. Jurnal

Cukier, K, dan Mayer-Schoenberger. 2013. The Rise of Big Data: How It's Changing The Way We Think About The World. Foreign Affairs, Volume 92 No. 3

Dunleavy, et. al. 2005. New Public Management Is Dead Long Live Digital-Era Governance. Oxford University Press: Journal of Public Administration Research and Theory (JPART) 16:467-494

Hansson, K, et. al. 2014. Open Government and Democracy: A Research Review. Sage Journal: Social Science Computer Review, 1-16

Henry, N. 1975. Paradigms of Public Administrations. Blackwell Publishing: American Society of Public Administration. Public Administration Review, Vol. 35, No. 4 (Jul- Aug., 1975) pp 378-386

Larquemin, A, et. al. 2016. Open Government Data and Evidence-based Socio-Economic Policy Research in India: an Overview. The Journal of Community Informatics, 12 (2), Special issue on Open Data for Social change and Sustainable Development, 120-147

Marume, S. B. M. 2016. Meaning of Public Administration. ,Quest Journals: Journal of Research in Humanities and Social Science Volume 4 Issue 6

Nath, Vikas. 2003. Digital Governance Models: Moving towards good governance in developing countries. The Innovation Journal: The Public Sector Innovation Journal, Volume 8 (1), article 4.

Susha, I., Zuiderwijk, A., Charalabidis, Y., Parycek, P., \& Janssen, M. 2015. Critical factors for open data publication and use: A comparison of city-level, regional, and transnational cases. Journal for e Democracy and Open Government, 7, 94-115.

Waldt, G Van Der. 2013. Public Administration and Management as Study Domain The Relevance Debate. African Journal of Public Affairs, Volume 6 No. 4

\section{Makalah}

Dunleavy, Patrick and Margetts, Helen. 2015. Design Principles for Essentially Digital Governance. In: 111th Annual Meeting of the American Political Science Association, 3 6 September 2015, San Francisco, USA

Fitriani, et. al. 2017. "Determinants of Intention to Use Open Data Website: An Insight from Indonesia". PACIS 2017 Proceedings. 234 


\section{Kebijakan: Jurnal Ilmu Administrasi \\ Volume 12, Nomor 2, Juni 2021 \\ E-ISSN: 2656-2820 \\ P-ISSN 1829-5762}

Fukuyama, Francis. 2013. "What Is Governance?.” CGD Working Paper 314. Washington DC: Center for Global Development.

Yu, H \& Robinson, D. 2012. The New Ambiguity of "Open Government". Los Angeles: University of Califoria LA Law Review Discourse No. 178

Xun, Wu dan He, Jiangwei. 2009. Paradigm Shift in Public Administration: Implications for Teaching in Professional Training Programs. Singapore: Lee Kuan Yew School of Public Policy National University of Singapore

\section{E. Laporan}

Curry, Dion. 2014. Trends For The Future Of Public Sector Reform: A Critical Review Of Future-Looking Research In Public Administration. European Union: COCOPS Report Work Package 8

Hanrahan, F. 2017. Menggunakan Bukti untuk Membuat kebijakan Sosial: Pelajaran dari Australia Sejak 2007 hingga 2017. Jakarta: Knowledge Sector Initiative Working Paper 21

McKinsey Global Institute. 2013. Open Data: Unlocking Innovation and Performance with Liquid Information

OECD. 2016. Kajian Open Government Indonesia: Hal-hal Pokok

Siregar, et. al. 2017. Inisiatif Pemerintahan Terbuka: Mojokerto, Pontianak, Tangerang. Jakarta: Centre for Innovation Policy and Governance (CIPG)

Ubaldi, Barbara. 2013. "Open Government Data: Towards Empirical Analysis of Open Government Data Initiatives", OECD Publishing: OECD Working Papers on Public Governance, No. 22

United Nations. 2013. Governance, Public Administration and Information Technology for Post2015 Development. New York: Department of Economic and Social Affairs Division for Public Administration and Development Management

United Nations. 2013. Rethingking Public Administration: An Overview. New York: Department of Economic and Social Affairs Division for Public Administration and Development Management

ODDC Report. 2013. Researching the emerging impacts of open data: ODDC Conceptual Framework.

F. Internet

Indah. 2017. "Pelayanan Publik dan Partisipasi Masyarakat". Melalui https://ppid.bandung.go.id/2017/08/pelayanan-publik-dengan-partisipasi-masyarakat/. [20/12/2019]

Sudjatmiko, Budiman. 2017. "Hidup Bersama Robot Cerdas". Melalui https://kompas.id/baca/opini/2017/12/16/hidup-bersama-robot-cerdas-2/ [16/12/2019]

Tanpa Pengarang. 2016. "Politik Open Government: Government 3.0: Negara Sebagai Platform”. Melalui http://pattiro.org/2014/02/politik-open-government-government-3-0negara-sebagai-platform/ [25/12/2019]

Tempo. 2016. "Pengguna Internet di Depok Baru 25 Persen". Melalui https://metro.tempo.co/read/733868/pengguna-internet-di-depok-baru-25-persen. $[1 / 1 / 2020]$ 


\section{Kebijakan: Jurnal Ilmu Administrasi}

Volume 12, Nomor 2, Juni 2021

E-ISSN: 2656-2820

P-ISSN 1829-5762

\section{G. Tesis}

Nugroho, Rininta Putri. 2013. A Comparison of Open Data Policies in Different Countries. the Netherlands: Delft University of Technology Master Thesis in MSc Program Engineering and Policy Analysis

\section{H. Dokumen}

DPADM/UNDESA, 2017. Open Government Data Assessment Methodology. New York: United Nations

International Open Data Charter Tahun 2015

Road Map Open Data Bandung 2016-2018. Bandung: Dinas Komunikasi dan Informatika Kota Bandung

Open Government Toolkit Tahun 2014.

Risalah Konferensi Internasional Inovasi Data Bagi Pembuat Kebijakan. Jakarta: Bappenas Tahun 2014.

Rencana Aksi Nasional Keterbukaan Pemerintah 2016-2017. Jakarta: Bappenas dan Open Government Indonesia Tahun 2016.

Open Government: Key Concepts and Benefits. Ontario: Information and Privacy Commisioner of Ontario Tahun 2016.

World Bank Support for Open Data 2012-2017 Tahun 2017.

Road Map Sekretariat Nasional Keterbukaan Pemerintah (Open Government Indonesia) 20172019 \& 2020-2024. Jakarta: Direktorat Aparatur Negara Kedeputian Politik Hukum Pertahanan dan Keamanan Bappenas Tahun 2017.

\section{G. Presentasi}

Kamil, Ridwan. 2016. Bandung Smart City. Melalui ipi.perpusnas.go.id/wpcontent/.../2016/10/Smart-City-Bandung-Ridwan-Kamil.pdf

\section{H. Video}

Humasbdg. (2014 Februari 27). 140222 International Open Data Day 2014. Berkas video diperoleh dari https://www.youtube.com/watch?v=1t75uEE8QPw\&t=1041s

Humasbdg. (2015 April 6). 150221 Bandung Open Data Summit and Challenge 2015. Berkas video diperoleh dari: https://www.youtube.com/watch?v=zVOXN8bJchI\&t=1717s 